\title{
A Capstone Project: The Electron Garden on the Green (EGG)
}

\section{Dr. Hayrettin B. Karayaka, Western Carolina University}

Bora Karayaka is an Engineering faculty at Kimmel School, Western Carolina University. He has worked as a Senior Engineer for smart grid and wireless communication industries for over ten years. He is currently responsible for teaching electric power engineering courses in the department.

Dr. Karayaka's research interests include power engineering education, ocean wave energy harvesting, identification, modeling and control for electrical machines and smart grid. He received his B.S. and M.S. degrees from Istanbul Technical University in Control and Computer Engineering and his $\mathrm{PhD}$ degree in Electrical Engineering from The Ohio State University.

\section{Dr. Robert D. Adams, Western Carolina University}

Dr. Adams is an Associate Professor of Electrical Engineering at Western Carolina University. His research interests include in digital image processing, biomedical signal processing and engineering education. 


\title{
A Capstone Project: The Electron Garden on the Green (EGG)
}

\begin{abstract}
Western Carolina University (WCU) would like to begin raising awareness of renewable energy and educating students and faculty on the importance of sustainable energy. WCU Facilities Management division has sought help in designing a project that will accomplish these goals. A $10 \mathrm{~kW}$ grid-tied PV system has been proposed that will be centrally located on campus. The system will serve as a living, learning laboratory for the campus community. The solar panels for the system will be mounted on three structures approximately 10 to 14 feet off the ground, which will also provide shade and shelter from the elements. Underneath the solar panels will be benches, tables, electrical outlets, and special hooks for students to hang hammocks. A small garden featuring native plant life will be planted around the solar panel structure. Small informational signage will be displayed throughout the garden informing visitors about the benefits of sustainable energy and how a PV system works.
\end{abstract}

As part of this effort, an engineering capstone project team was responsible for researching, designing, and proposing a PV system for Western Carolina University. A shading analysis was first conducted in multiple locations on campus to determine where the most sunlight hours occurred. The National Renewable Energy Laboratory's PVWatts ${ }^{1}$ Calculator was later utilized to estimate how much energy the system would generate per year and how much money the system would save the university. Greenhouse gas savings estimates were also calculated to determine the amount of reduction in $\mathrm{CO}_{2}$ emissions. Western Carolina University's lead architect provided assistance with the structural design of the EGG and estimation of construction costs. Since the university is recommended to use a third party to install the PV system, a local installer was contacted to gather a professional opinion. The proposal was later submitted to the WCU Sustainable Energy Initiative (SEI) Committee, which allocates funds for sustainable energy projects on campus. After a formal presentation by the engineering capstone team, the WCU SEI Committee has decided to move forward with the project.

The preliminary research involved gathering information on exactly how a PV system works. Further research revealed the necessity for Maximum Power Point Tracking in solar inverters. The engineering capstone team has investigated the benefits of oversizing a PV system with a 1.25 array-to-inverter ratio $^{2}$. A vital part of this research involved emissions reduction calculations and payoff estimates. The emissions reduction calculations showed that the system would reduce $\mathrm{CO}_{2}$ emissions of the school by approximately five tons annually. Payoff of the system was calculated to be approximately 39.25 years. If the university were able to claim the $35 \%$ North Carolina solar energy tax credits, the payoff would be reduced to approximately 12 years.

Western Carolina University is situated in a fantastic location for solar energy to thrive, which makes the EGG a realistic and highly-desirable project. The research by the capstone team determined that the best option for WCU to raise awareness and educate students about renewable energy is to implement a flagship project that would serve to accomplish these goals. 


\section{Introduction}

Recognizing our additional need for clean energy in $21^{\text {st }}$ century, electric energy generation through renewable sources (especially wind and solar) has gained quite a lot of momentum over the recent years. Total non-hydro renewable energy generation (wind, solar, geothermal and biomass) in the U.S. for all sectors increased by 10.1 percent in 2014, following a 16.1 percent increase in 2013. The fastest-growing component in 2014 was solar (thermal and photovoltaic) power with a 95.8 percent increase. Wind energy generation increased 8.2 percent. Since 2009, generation from non-hydro renewables has almost doubled. In 2014, total non-hydro renewable energy generation surpassed conventional hydroelectric generation for the first time in the U.S. history. Moreover, total utility scale solar for the first time surpassed geothermal power generation in 2014. Figure 1 displays the exponential growth of utility scale solar generation since 2001. In 2014, renewable energy generation made up 13.2 percent of total generation. The largest three contributors were hydro (6.3 percent), wind (4.4 percent), and biomass (1.6 percent), followed by solar ( 0.4 percent). On the other hand, electrical energy production from fossil fuel sources coal has still the largest share of $38.6 \%$ which is followed by natural gas with a share of $27.5 \%{ }^{3}$.

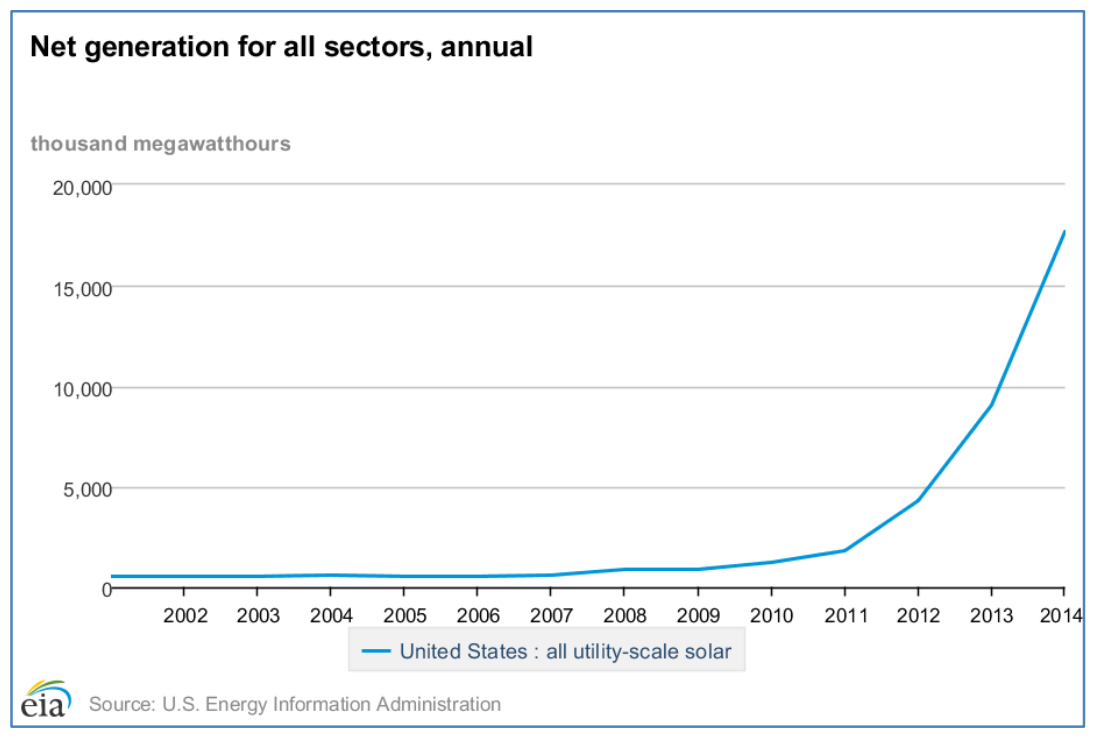

Figure 1. Growth of Solar Energy Generation ${ }^{3}$

Solar energy is one of the most distributed sources of renewable energy and it has a tremendous growth potential. On the other hand, wind resources are mostly limited to the areas that are away from densely populated regions ${ }^{4}$ and new wind installations require hefty investments on transmission infrastructure. Therefore, it is a prime importance to prepare and educate the next generation of workforce for the solar industry. According to 2015 National Solar Jobs Census released by The Solar Foundation, the solar industry now employs over 208,000 Americans and has grown $123 \%$ since $2010^{5}$. Key findings from the census include:

- The solar workforce grew at a rate 12 times faster than the overall economy;

- This is the third consecutive year that solar employment grew by approximately $20 \%$; 
Increasing interest in solar energy related capstone projects can also be found in the literature. For example, ASEE-ECCD division alone hosted 5 paper presentations in 2015 Annual Conference, Seattle, WA ${ }^{6-10}$.

The unique nature of the capstone project presented in this paper is that it details the design steps for a practical grid-tied solar PV system. Shading analysis, solar panel and inverter selection, energy production estimates, carbon footprint reduction estimates, cabling related analysis for grid tie-in, cost recovery period calculations and proposal development for funding comprise the major milestones in this study.

The following sections describe the capstone project model at Western Carolina University (Section 2), project design steps (Section 3), lessons learned, results and findings (Section 4), and Conclusions (Section 5).

\section{Engineering Capstone Projects at WCU}

At Western Carolina University, engineering and technology students are required to participate in a two-semester senior capstone project. Students work on a challenge proposed by a project sponsor who has been invited by the Center for Rapid Product Realization, an EDA-designated university center, to submit "real-world" problems that are open-ended, complex, require innovation and self-directed learning and are of sufficient scope to require a team approach.

Each capstone team is made up of two to four students in a multidisciplinary setting selected from four majors: electrical engineering, electrical and computer engineering technology, BS in engineering (mechanical concentration), and engineering technology. Each capstone student team works with the course instructor, a faculty mentor, and a mentor selected by the project sponsor. Student teams use a stage/gate process, progressing from a project proposal to a minimum of three conceptual designs; continuing to a preliminary design review, a critical design review, and fabrication and testing of a prototype or proof of concept; and finishing with a wrap-up of documentation, test results and modifications, if needed, to resolve any issues revealed through testing.

Students gain valuable experience by working on a "real-world" project; analyzing and solving engineering problems; learning teamwork and presentation skills; setting goals, specifying deliverables and meeting deadlines; testing and modifying their work; and achieving measurable results.

The capstone experience is implemented with two three credit hour courses: ENGR 400 Engineering Capstone I and ENGR 450 Engineering Capstone II. In ENGR 400, students from capstone teams formulate project specifications, develop a work plan, self-select individual roles, research, analyze, and present potential design solutions including budgets, and provide weekly status briefings to project sponsors. ENGR 400 culminates with a formal design proposal presented in a public forum to project sponsors and any interested faculty and students. In ENGR 450 , students in capstone stone projects normally implement the proposed design. In the Electron Garden on the Green project, implementation would be accomplished after the capstone 
students had completed the ENGR 400-450 sequence. Therefore the goals of ENGR 450 was modified for these students with the requirement that they had to formally submit the design proposal to the Facilities Management division of the university upon completion of ENGR 450. The project presented in this paper was sponsored by Western Carolina University Facilities and Management division. The team members included two Electrical Engineering (EE) majors and one Electrical and Computer Engineering Technology (ECET) major.

\section{EGG Project Design Steps}

The EGG is a project designed to raise awareness of the benefits of solar energy as well as the ability to combine solar energy with differing interdisciplinary interests for a common educational good. The project will be primarily concerned with the installation of a 10kW solar photovoltaic (PV) system geared towards supplying power to Western Carolina University's grid. This will be an effort to decrease the amount of money that WCU spends on electricity yearly, to educate students about solar electricity, and finally to reduce the amount of $\mathrm{CO}_{2}$ released by WCU's consumption of non-renewable energy sources each year (either directly or indirectly). The project had the following requirements:

- Stay below overall budget of \$65K (available funds for all potential SEI projects).

- Make it visible to students in campus.

- The project should educate students and raise awareness for sustainable energy.

- The project should have multiple uses, i.e. providing shade as well as generating power to the grid.

- The design should incorporate solar photovoltaic modules.

- Develop a proposal to be presented to SEI committee.

The design steps completed in this project were:

1. Investigating appropriate panels, inverter, cabling

2. Conducting shading analysis and measuring cable lengths.

3. Using PVWatts to estimate annual $\mathrm{kWh}$, optimal tilt angle, and savings.

4. Getting together with a local installer concerning necessary NEC (National Electric Code) standards which deal with the interconnection in electric tie-in location.

5. Designing the PV system using "overloading" practices to maximize efficiency.

6. Factoring in efficiency losses of the solar cells over 20 years.

7. Calculating greenhouse gas emissions offset by the design.

8. Making use of the structural design provided by Facilities and Management division

9. Investigating educational component for solar power generation statistics.

Each team member was responsible for specific tasks in this project. Due to the scale of some specific tasks, multiple members were collaborating in these tasks. The details of these roles were as follows.

Team member $1-\mathrm{CO}_{2}$ emissions calculations, NEC standards research, shading field study, and cable selection.

Team member 2 - Maximum Power Point Tracking (MPPT) analysis, inverter selection, PV system "over-sizing” study, NEC standards research, shading analysis, presentation planning. 
Team member 3 - Solar panel selection, payoff calculations, $\mathrm{CO}_{2}$ emissions calculations, shading field study, shading analysis, and original panel layout and calculations.

\section{EGG Project Results and Lessons Learned}

\section{Site Analysis}

The team came up with several different options and layouts for three different proposed locations for the Electron Garden on the Green (EGG) in the university campus. The drawings for proposed site layouts for a specific solar panel selection is shown in Figure 2.

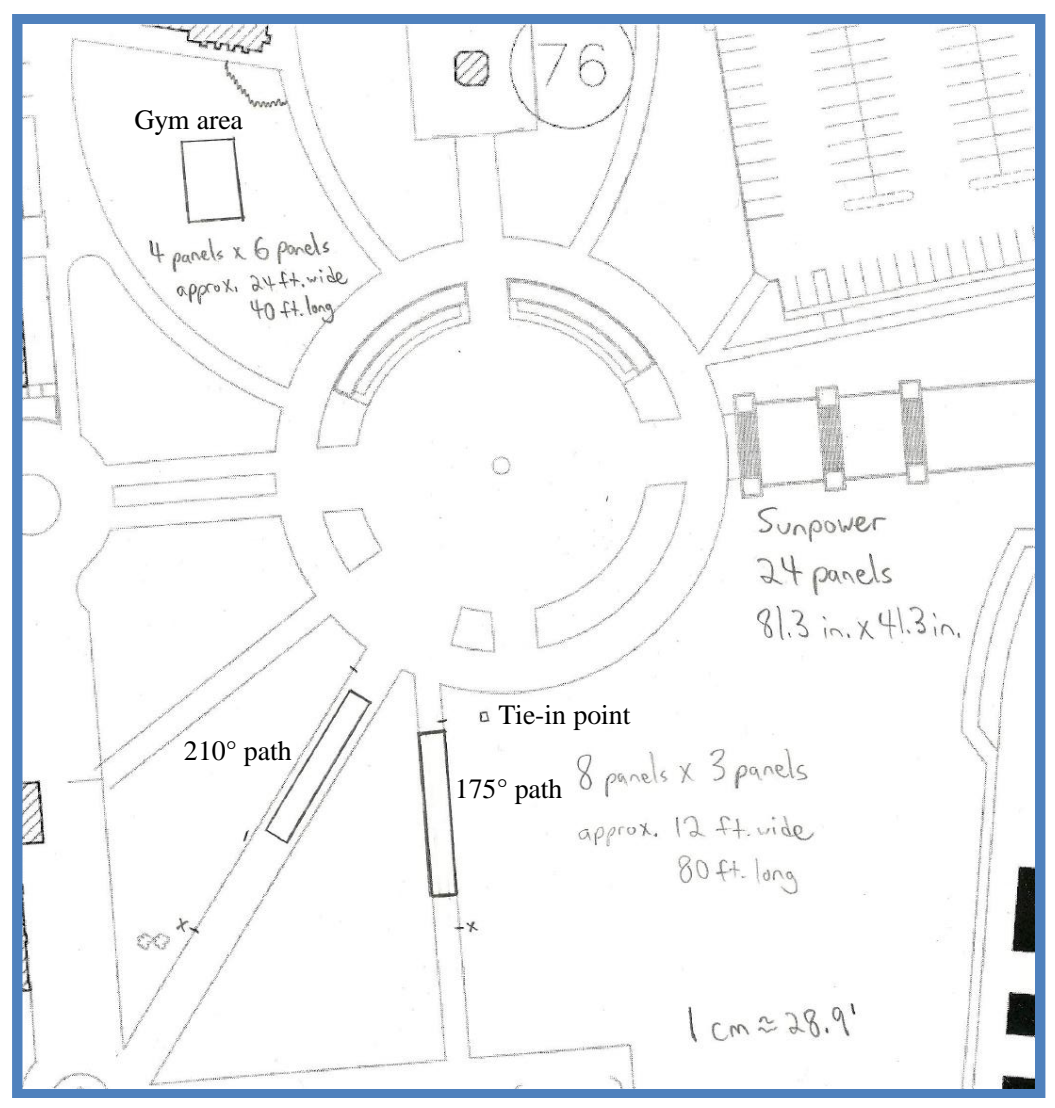

Figure 2. Three potential locations drawn by rectangles in the case of SunPower brand panels (Courtesy of the university architect Mr. Galen May)

The first location considered was the large green space near the gym (the rectangle in the upper left hand corner in Figure 2). This location was ruled out once the team considered the cost it would require to run cabling across the Central Plaza to the tie-in point located near the $175^{\circ}$ path (from true north). The green space near the gym is also a recreational area for many university functions.

The second location considered was the $210^{\circ}$ (from true north) path due to its minimal shading and ample space for solar panels to be displayed above the walkway. This location was ruled out 
once it was understood that displaying the panels above the walkway wouldn't be a viable option.

This left the team with third and final option: the green space adjacent to the $175^{\circ}$ path. This location is very convenient in terms of cost because of its proximity to the only tie-in point on the Central Plaza. The $175^{\circ}$ path also is the best location for a PV system according to the shading analysis (see Shading Analysis section). The only downside to this location is that it will take up green space previously used by students for recreational activities. However, it was originally projected that the EGG would still leave plenty of space for student activities and also provide a new area to be used as a living and learning laboratory.

The team consulted with the university architect in order to make use of the structural design provided by Facilities and Management division. An architect drawing and pictorial diagram of the proposed structure is shown in Figure 3. As shown in this figure, there will be three bays solar panels in a central campus location. These panels will provide a shaded area for students to relax or study outside. Concrete cylinders under the panels will provide seating as well as receptacles to power portable electronic devices.

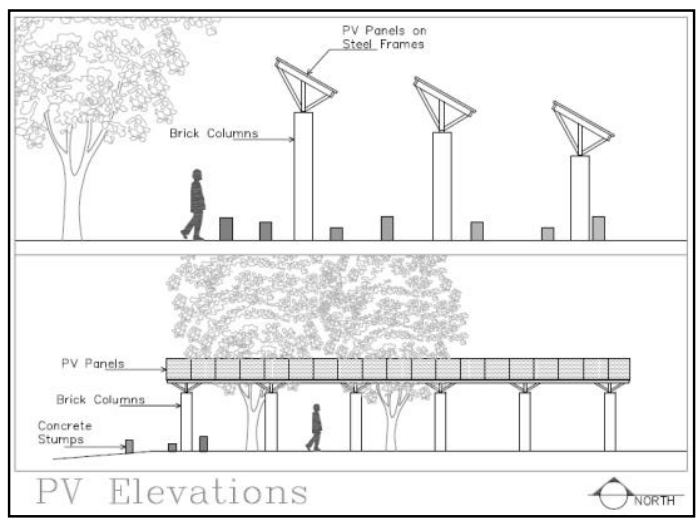

(a)

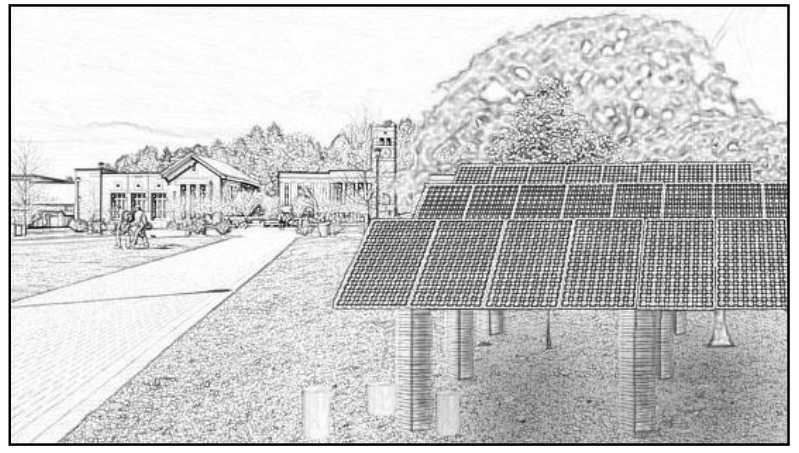

(b)

Figure 3. a) Architect drawing and b) pictorial diagram of the proposed array of solar panels. Diagrams furnished courtesy of WCU, University Architect

\section{PV Panel Selection}

The team found several viable options for solar panels which included SunPower, Kyocera, Zebra Energy and SolarWorld brands. Among these four, the top choice was the SolarWorld 280 Mono Black solar panel because of its low price, reliability, and the fact that the panels are manufactured in the U.S. In addition, the amount of space the team had to work with due to this choice was not really a concern at the $175^{\circ}$ path location. The final design is a $10 \mathrm{~kW}$ photovoltaic system that will utilize an array of 40 SolarWorld 280 Mono Black 280 Watt panels. The panels are elevated so as to permit foot traffic in this very open and heavily used central campus location. Each solar panel develops an output voltage of 31.2 volts at the maximum power output of 280 Watts. The final design proposal is to connect two groups of 20 solar panels in series to obtain two independent sources, each capable of delivering $5.6 \mathrm{~kW}$ of electric power at an output DC voltage of 624 volts and an output current of 8.98 Amps DC. 


\section{Inverter Selection}

The team consulted with a local solar panel installer concerning necessary NEC (National Electric Code) standards which deal with the interconnection of the system to the electric tie-in location. This effort helped the team design a system that would have sufficient overcurrent protection while operating within standardized temperature limits for all subsystems. Becoming familiar with the NEC standards permitted the team to take advantage of higher efficiency operation of inverters using "overloading" practices, making the solar panel output power greater than the rated inverter input power. This allows for optimal maximum power point tracking (MPPT). These were an important lessons learned for the team since the selection of inverters were originally based on the rating criteria specified by the solar panels.

The electrical tie-in point (shown in Figure 2) requires a 208V-3Ф connection. Based on this voltage and phase criteria, the top choice for an inverter was the Fronius Symo 7.0. Moreover, the Fronius Symo 7.0 has wireless capability which will be linked to the campus Wi-Fi in order to display real time data of PV system. The Fronius Symo 7.0 also satisfies the requirement for PV inverters to meet the overcurrent capability described by NEC 690.8(B)(1)(a) standard. The Fronius Symo inverter will simultaneously convert the two 624 VDC networks to one three phase 208 VAC line with an energy efficiency of over $95 \%$ at peak operation.

\section{Power Cable Selection}

Cabling related analysis was originally conducted accounting for three different locations shown in Figure 2 AC (208V-3Ф) conductors turned out to be much more economical in comparison to DC $(624 \mathrm{~V})$ conductors. Most appropriate choice for the project was (1/0) AWG rated aluminum conductors (3+ground) rated for 27.76A. The catalog number for this wire is "1A3SERGX1000". The conductor has $2.81 \%$ or less voltage drop @ $500 \mathrm{ft}$. After the location search was narrowed down to the $175^{\circ}$ path location, the cabling became a less of a concern due to the close proximity of panels to the tie-in location.

\section{Shading Analysis}

PVWatts is a calculation tool used to estimate annual $\mathrm{kWh}$, optimal tilt angle, and savings, based on the geographic location and solar system configuration. The team used this tool to estimate a baseline for the expected energy production over an entire year. This tool roughly considers shading.

In order to more accurately assess savings and the time to payoff of the proposed solar array, it was necessary to analyze the site according to the amount of available sunlight. Figure 4 shows a profile of the horizon at the proposed site along with the trace of the sun throughout the day, both at summer solstice and at winter solstice. At summer solstice, the sun is clearly visible from about 7:30 am until about $7 \mathrm{pm}$. At winter solstice, the sun is clearly visible from about 10 am until about $4 \mathrm{pm}$. Using a smart phone application "Solar Shading" by Comoving Magnetics (http://comovingmagnetics.com/wp/?app=solar-shades), the team was able to collect data concerning the relative amount of available solar power at the site. From this data, the team displayed (Figure 5) the shading losses throughout the year relative to the annual peak available solar power. 


\section{5 end of garden - Sun Path}

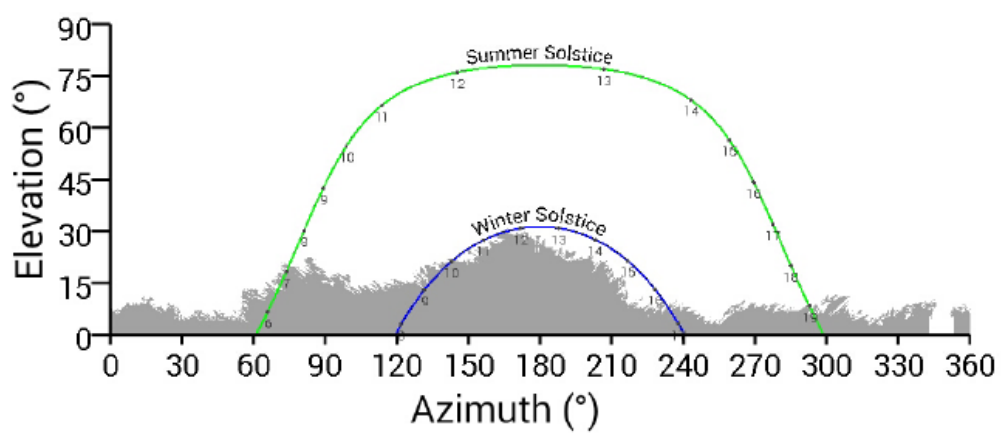

Figure 4. Elevation versus azimuth of the sun location throughout the day at summer solstice (green) and at winter solstice (blue).

\section{5 end of garden - Monthly Losses}

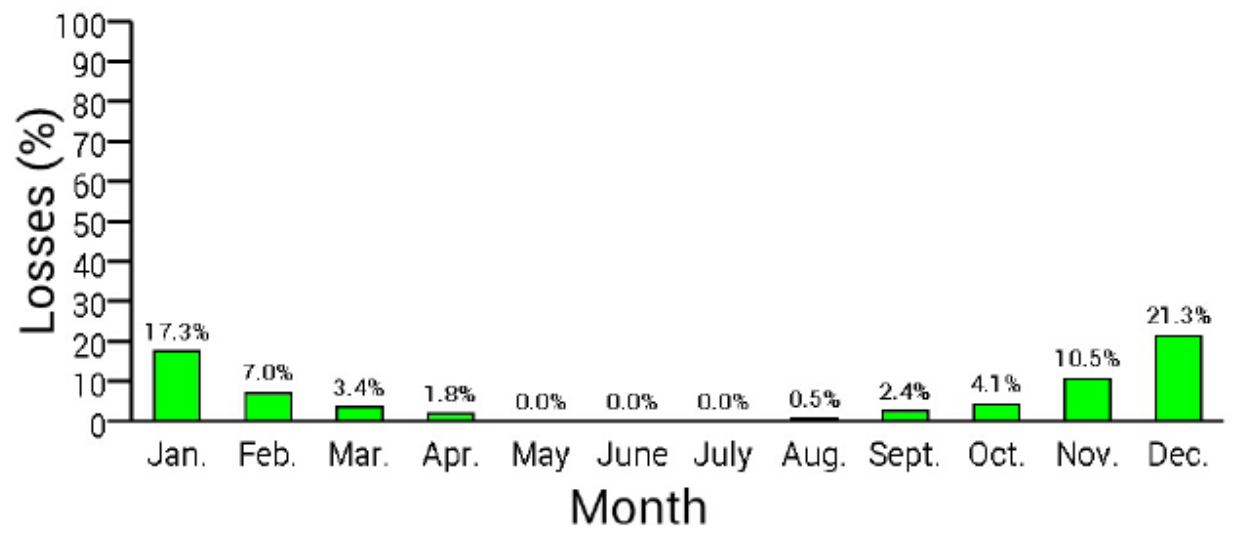

The total yearly sun hour losses are $5.7 \%$ due to shading.

Figure 5. Shading losses relative to the annual peak available solar power versus month.

\section{Cost Analysis}

Since every panel decreases in efficiency over its lifespan, the team needed to account for those losses. On average a panel will drop to $80 \%$ of its rated power after 25 years of operation. The estimated annual energy cost savings to the university versus time is plotted in Figure 6 . These estimates take into account shading losses for the selected system as well as loss of solar panel efficiency over time. These savings estimates were based on an average blended energy cost (usage and demand rates) of approximately $\$ 0.063$ / $\mathrm{kWh}$ paid by WCU. The estimated energy production in year 1 for the selected site (with shading losses of $3.6 \%$ ) is 13,199 kWh. Total cost for the PV system is estimated to be $\$ 30,000$, based on the average figure set by the local installer. At this cost, the system will pay for itself in 39 years. 


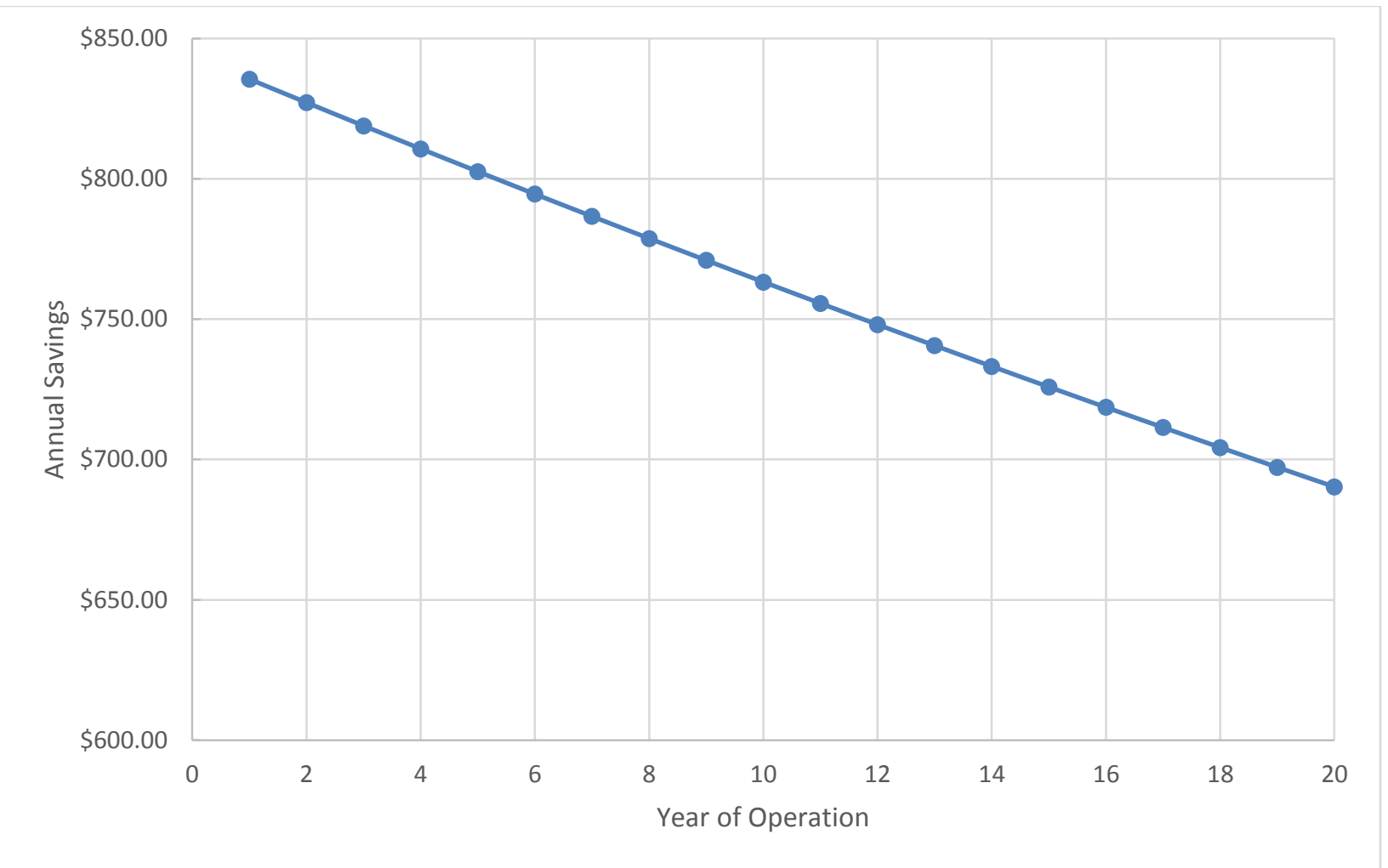

Figure 6. Annual energy cost savings versus time

\section{Analysis of Greenhouse Gas Reduction}

The team made an analysis of the estimated yearly greenhouse gases reduction that the proposed solar PV system will provide. A summary of the calculations are shown in Table 1. The result of this study showed a reduction of $4478 \mathrm{~kg}$ (4.478 metric tons) of $\mathrm{CO}_{2}$ per year. This amount is equivalent to the average emission of one passenger vehicle in the US ${ }^{11}$. The team researched the distribution of sources of energy in North Carolina and the efficiencies of power production from each of these sources, as shown in the Adjustable Values section of Table 1. Detailed steps are as follows:

Steps 1 and 2: The team tabulated the average month-by-month energy consumption on campus obtained from the Facilities and Management utility records ${ }^{12}$ and calculated annual consumption including transmission line loss.

Steps 3-6: From energy consumption data, the team computed the amount of energy use due to $\mathrm{CO}_{2}$ emitted components and from these results computed the average amount of $\mathrm{CO}_{2}$ emitted by coal and natural gas due to university energy usage.

Steps 7: The team computed the projected average annual energy generated by the proposed PV system.

Steps 8-11: The team computed the projected amount of $\mathrm{CO}_{2}$ reduction by the proposed PV system. 


\section{Design Challenges}

The major challenges faced by the team and faculty throughout the project were primarily on site identification/selection, shading analysis and inverter selection that complies with appropriate NEC standards. These items were originally not accounted for. The three sites (Figure 2) that the team diligently analyzed for efficiency were not approved for installation by upper level university committee. However, the experience gained was valuable and effectively carried on with the former team member who currently interns at WCU Facilities and Management division to help complete the project. Shading analysis was also a new concept which was later explored with the help from the staff at Facilities and Management. Finally, understanding of NEC standards in inverter selection was another challenging topic. NEC Standards was later clarified by communicating with a local installer. In addition, one team member discovered the string sizing tool available for various inverter brands on-line ${ }^{13}$, which really simplified the inverter selection and solar array configuration.

\section{Assessment of Student Learning Outcomes}

For this project to have an impact on the learning of general student body at WCU, the student team investigated opportunities for an educational component to solar power generation statistics. The PV system will use an inverter connected via Wi-Fi to an LCD smart TV showing real time data detailing savings and power output in a highly visible public space on campus. There will also be educational signage at the PV site detailing how the system works. Multiple departments at WCU may be involved in this project. The Biology Department may assist with scientific nomenclature of plants in the garden. The Art Department, Interior Design Department, and Parks and Recreation may be involved with the layout and management of the EGG. Facilities Management and Resource Management will oversee the maintenance of the garden and PV system. Once completed, the EGG will serve as a living, learning laboratory to WCU students and faculty.

ABET-ETAC student outcomes a and $\mathrm{f}$ were assessed for the one ECET major on the capstone team, and ABET-EAC criteria $\mathrm{c}$ and e were assessed for the two EE majors on the capstone team. To assess these student outcomes, several performance indicators were developed as shown in Table 2. Rubrics were developed for each performance indicator (PI). The activities included in the assessment are student reports, oral presentations, and poster presentations. For each student, possible scores of 4-Excellent, 3-Satisfactory, 2-Marginal, 1-Unsatisfactory were assigned to each performance indicator. The scores for each performance indicator were averaged to compute the score for each student outcome. For example, PI scores for al through a4 were averaged to compute the score for ABET-ETAC outcome a. Aggregate results to evaluate how this project has equipped the students with insights, knowledge, and skills for renewable energy (especially for Solar PV) are presented in Table 3. 
Table 1: Greenhouse Gases Calculations

\begin{tabular}{|l|r|}
\hline & 1) kWh '12 (kWh) \\
\hline Jan & $2,856,000$ \\
\hline Feb & $2,721,600$ \\
\hline Mar & $2,976,000$ \\
\hline Apr & $2,846,400$ \\
\hline May & $2,688,000$ \\
\hline Jun & $2,577,600$ \\
\hline Jul & $2,966,400$ \\
\hline Aug & $2,625,600$ \\
\hline Sep & $3,091,200$ \\
\hline Oct & $2,932,800$ \\
\hline Nov & $2,707,200$ \\
\hline Dec & $2,424,000$ \\
\hline Total & $33,412,800$ \\
\hline
\end{tabular}

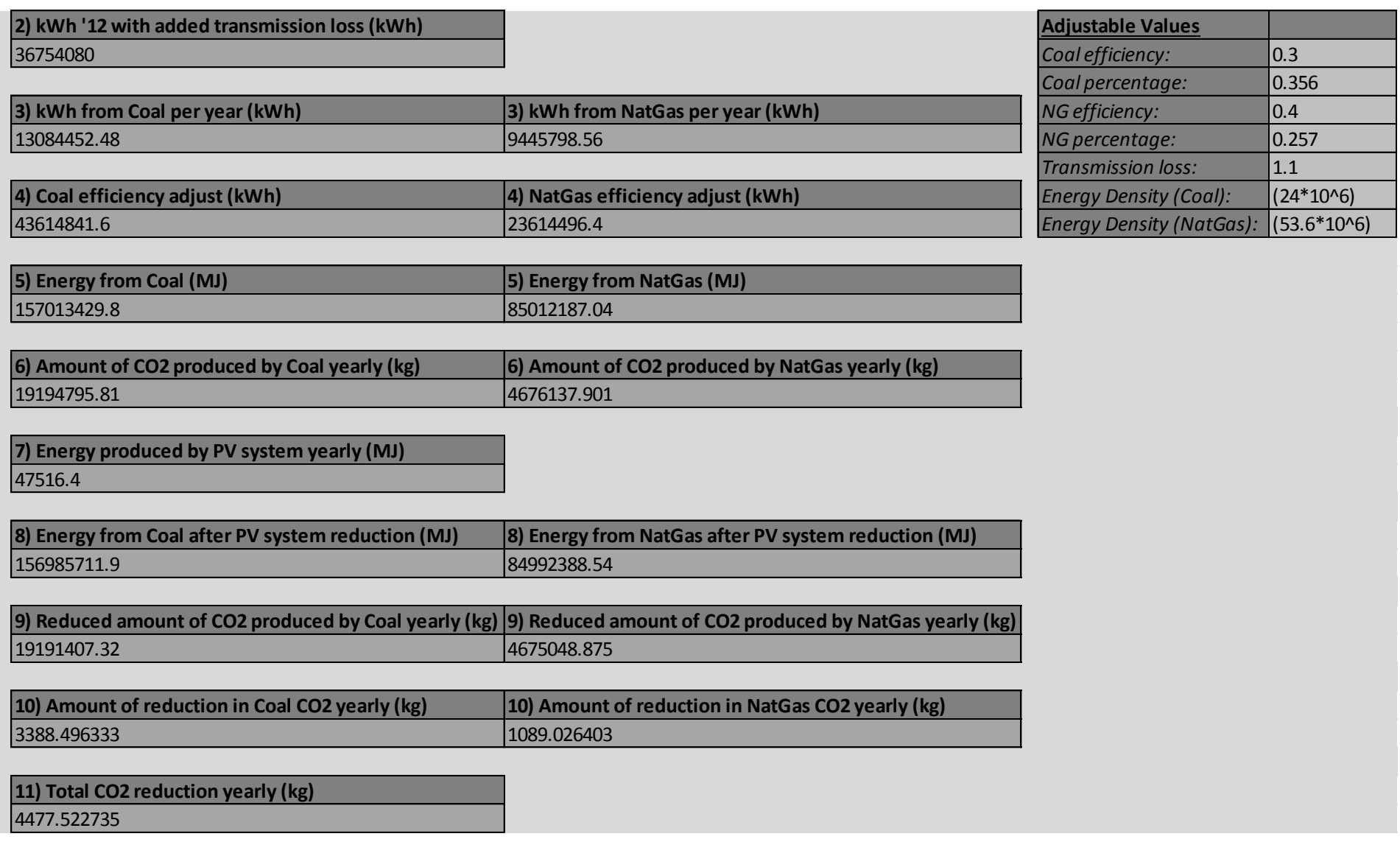


Table 2. Assessed ABET Student Outcomes and the Associated Performance Indicators

\begin{tabular}{|c|c|}
\hline ABET Student Outcome & Performance Indicator \\
\hline \multirow{4}{*}{$\begin{array}{l}\text { ETAC (a) An ability to select and } \\
\text { apply the knowledge, techniques, } \\
\text { skills, and modern tools of the } \\
\text { discipline to broadly-defined } \\
\text { engineering technology activities }\end{array}$} & $\begin{array}{l}\text { (a.1.) - An ability to select and apply the knowledge } \\
\text { of the discipline to broadly-defined engineering } \\
\text { technology activities }\end{array}$ \\
\hline & $\begin{array}{l}\text { (a.2.) - An ability to select and apply the techniques } \\
\text { of the discipline to broadly-defined engineering } \\
\text { technology activities }\end{array}$ \\
\hline & $\begin{array}{l}\text { (a.3.) - An ability to select and apply the skills of the } \\
\text { discipline to broadly-defined engineering } \\
\text { technology activities }\end{array}$ \\
\hline & $\begin{array}{l}\text { (a.4.) - An ability to select and apply the modern } \\
\text { tools of the discipline to broadly-defined } \\
\text { engineering technology activities }\end{array}$ \\
\hline \multirow{3}{*}{$\begin{array}{l}\text { ETAC (f) An ability to identify, } \\
\text { analyze, and solve broadly-defined } \\
\text { engineering technology problems }\end{array}$} & $\begin{array}{l}\text { (f.1.) - An ability to identify broadly-defined } \\
\text { engineering technology problems. }\end{array}$ \\
\hline & $\begin{array}{l}\text { (f.2.) - An ability to analyze broadly-defined } \\
\text { engineering technology problems. }\end{array}$ \\
\hline & $\begin{array}{l}\text { (f.3.) - An ability to solve broadly-defined } \\
\text { engineering technology problems. }\end{array}$ \\
\hline \multirow{3}{*}{$\begin{array}{l}\text { EAC (c) An ability to design a system, } \\
\text { component, or process to meet desired } \\
\text { needs within realistic constraints such } \\
\text { as economic, environmental, social, } \\
\text { political, ethical, health and safety, } \\
\text { manufacturability, and sustainability }\end{array}$} & $\begin{array}{l}\text { (c.1.) - An ability to design a system, component, or } \\
\text { process to meet desired needs. }\end{array}$ \\
\hline & $\begin{array}{l}\text { (c.2.) - An ability to apply realistic constraints within } \\
\text { a system, component, or process design. }\end{array}$ \\
\hline & $\begin{array}{l}\text { (c.3.) - An ability to identify and use appropriate } \\
\text { technical literature }\end{array}$ \\
\hline \multirow{3}{*}{$\begin{array}{l}\text { EAC (e) An ability to identify, } \\
\text { formulate, and solve engineering } \\
\text { problems }\end{array}$} & (e.1.) - An ability to identify engineering problems. \\
\hline & (e.2.) - An ability to formulate engineering problems. \\
\hline & (e.3.) - An ability to solve engineering problems. \\
\hline
\end{tabular}

Table 3. Capstone Team Assessment Results

\begin{tabular}{|c|c|}
\hline Student Outcome & $\begin{array}{c}\text { Team's Average } \\
\text { Score }\end{array}$ \\
\hline ABET-ETAC outcome a & 3.4 \\
\hline ABET-ETAC outcome $\mathrm{f}$ & 3.2 \\
\hline ABET-EAC outcome c & 3.5 \\
\hline ABET-EAC outcome e & 3.7 \\
\hline
\end{tabular}




\section{Conclusion}

This study has documented the efforts of a student engineering capstone team to design and present a formal proposal for a campus PV energy generation system. The proposal demonstrated the amount of energy savings and reduction in the campus carbon footprint as well as potential educational opportunities. As a result of the team's effort, the project has been funded, construction is currently underway and the facility is scheduled for an opening in April 2016. This was an excellent demonstration of a capstone project involving students solving a "real-world" engineering problem, requiring project management skills, team work, life-long learning, analytical ability, and presentation skills. One strong indicator of this being a successful team project is that all three students have been employed in the related field. One is working as an engineer at a utility solutions provider. Another is working for the Facilities and Management Division to help complete the project. The third is working as an engineer for a regional electric utility cooperative.

Future work includes collaboration with the team member that currently interns for the completion of the project in various aspects of installation. In addition, after the project is completed, an important future work is the thorough analysis of the solar PV system's operational characteristics in terms of actual savings and carbon foot print reduction through the educational component available to the campus community.

\section{Bibliography}

1. National Renewable Energy Laboratory’s PVWatts Calculator: http://pvwatts.nrel.gov/

2. Frank Andorka, "Increasing Your Array-To-Inverter Ratio Improves Solar Economics," Solar Power World, June 24, 2013. Available at http://www.solarpowerworldonline.com/2013/06/supersize-it-oversize-your-arrayto-inverter-ratio-to-improve-solar-system-performance/

3. U. S. Energy Information Administration, "Electricity Data Browser," Jan. 17, 2016, available online http://www.eia.gov/electricity/data/browser/\#/topic/0?agg=2,0,1\&fuel=pefpu\&geo=g\&sec=g\&freq=A\&start=2 $001 \&$ end $=2014 \&$ ctype $=$ linechart \&ltype $=$ pin \&rtype $=$ s \& maptype $=0 \& r s e=0 \& p i n=$

4. N. Mohan, Electric Power Systems: A First Course. MA: John Wiley \& Sons, Inc., 2012

5. Solar Jobs Census available at http://www.thesolarfoundation.org/solar-jobs-census/.

6. Ososanya, E. T., \& Haghani, S., \& Mahmoud, W. H., \& Lakeou, S., \& Diarra, S. D. (2015, June), Design and Implementation of a Solar-Powered Smart Irrigation System. Paper presented at 2015 ASEE Annual Conference and Exposition, Seattle, Washington. 10.18260/p.23792.

7. Guvench, M. G., \& Swanson, P. W., \& Wacker, K. M. (2015, June), Concentrated Solar, Dual Axis-Tracking, Multi-junction GaAs Cell Photovoltaic System Design for Efficient Solar Energy Conversion. Paper presented at 2015 ASEE Annual Conference and Exposition, Seattle, Washington. 10.18260/p.23727.

8. Megri, A. C. (2015, June), Feasibility Study of Renewable Energy Sources for Energy Efficiency. Paper presented at 2015 ASEE Annual Conference and Exposition, Seattle, Washington. 10.18260/p.24107.

9. Tebbe, P. A., \& Chetrit, A., \& Aleckson, L. (2015, June), Design and Construction of a Renewable and HVAC Technologies Testbed, "Shack”. Paper presented at 2015 ASEE Annual Conference and Exposition, Seattle, Washington.

10. Louie, H., \& Szablya, S., \& Miguel, A. (2015, June), Student Design of a Sustainable Microgrid for Rural Kenya. Paper presented at 2015 ASEE Annual Conference and Exposition, Seattle, Washington. $10.18260 /$ p. 24750 .

11. Office of Transportation and Air Quality (2014, May), Greenhouse Gas Emissions from a Typical Passenger Vehicle. , U.S. Environmental Protection Agency Report EPA-420-F-14-040a.

12. WCU Facilities and Management utility bill spreadsheet 2000-2014.

13. CivicSolar, "String Sizing Tools and Choosing and Inverter," Mar. 22, 2016, available on-line https://www.civicsolar.com/resource/string-sizing-tools-and-choosing-inverter. 